\title{
Gendered Reflections? Extremism in the UK's Radical Right and al-Muhajiroun Networks
}

\section{Elizabeth Pearson}

To cite this article: Elizabeth Pearson (2020): Gendered Reflections? Extremism in the UK's Radical Right and al-Muhajiroun Networks, Studies in Conflict \& Terrorism, DOI: 10.1080/1057610X.2020.1759270

To link to this article: https://doi.org/10.1080/1057610X.2020.1759270

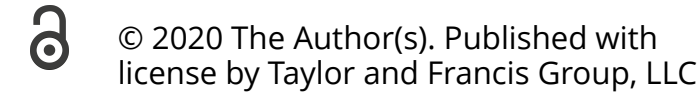

曲 Published online: 25 May 2020.

Submit your article to this journal $\pi$

Џلll Article views: 432

Q View related articles $\sqsubset$

View Crossmark data $\nearrow$ 


\title{
Gendered Reflections? Extremism in the UK's Radical Right and al-Muhajiroun Networks
}

\author{
Elizabeth Pearson \\ School of Law and Criminology, Swansea University, Wales, UK
}

\begin{abstract}
The rise of populism and the radical right alongside ongoing global recruitment by jihadist groups has seen academics and popular discourse alike note parallels between the two. In particular, authors have emphasized gendered similarities between the movements. Based on 'close-up' ethnographic research, this article empirically shows how gender produces group members' activism in two extreme movements: a network linked to the U.K.'s banned Islamist group al-Muhajiroun; and activists for the English Defence League, Britain First and other anti-Islam(ist) groups. Through a gendered analysis, the article problematizes assertions that the two movements mirror one another. In particular, it emphasizes the ways in which gender produces fragmentation across the anti-Islam(ist) movement, contrasted with a more consistent gendered logic in those networked to al-Muhajiroun. Its key contribution is to use ethnographic research to evidence the ways in which group members' gendered activism ultimately undercuts group ideals.
\end{abstract}

"Islamophobia is fear of Islam, and people should be afraid".

Interview, Akash, 6 February 2017

"The rapid growth of militant Islam is leading to the suppression of women, freedom of speech and racist attacks. . We will make Britain a beautiful country once again where you can leave your door unlocked and your children can play in the streets."1

Britain First, Mission Statement

\section{Introduction}

Gender matters in understanding terrorism and extremism, and this goes beyond simple considerations of women's roles in violent groups. Gender is evident in extremist narratives, and ideology. Daesh propaganda has for instance portrayed jihadi men as 'real' men, contrasted with male emasculation in the West. ${ }^{2}$ Meanwhile, nationalist violence has long relied on constructed dichotomies of insider/outsider, masculine/feminine, and

CONTACT Elizabeth Pearson e.g.pearson@swansea.ac.uk $\Theta$ School of Law and Criminology, Swansea University, Wales, UK. $(9$ @lizzypearson

(C) 2020 The Author(s). Published with license by Taylor and Francis Group, LLC

This is an Open Access article distributed under the terms of the Creative Commons Attribution License (http://creativecommons.org/ licenses/by/4.0/), which permits unrestricted use, distribution, and reproduction in any medium, provided the original work is properly cited. 
the masculine/male read as superior to and protective of the feminine/female. ${ }^{3}$ Extremism is not limited to one ideology. Yet at different times, different forms of extremism are more prevalent, and attract greater government attention. In 2017, the U.K. experienced four major terrorist attacks, three of which were inspired by Salafijihadist ideology, and one - an attack on London mosque-goers - by opposition to Islam. Together, these attacks led to some 40 deaths. Since then, the British Government has increased pressures on the far right, as this threat is growing. ${ }^{4}$ The intelligence services now lead investigation of far right threats, under a counterterrorism remit. ${ }^{5}$ At the same time, the counter-radicalization policy, Prevent, initially aimed at the prevention of Islamist violence, is increasingly applied to the far right. Additionally, authors have suggested these movements share gendered norms and practices. For instance, that they embody similar 'toxic' attitudes to women, adhere to a strict gender binary in which the roles of men and women are oppositional and distinct, ${ }^{6}$ and that their ideologies mirror one another in gendered ways. ${ }^{7}$

This paper engages with this 'similarity' hypothesis, using ethnographic methods to explore gender in two of the most significant movements designated extreme in the U.K. at this time: the anti-Islam(ist) radical right, opposed to the perceived Islamization of Britain and Europe; and an Islamist network linked to and including Anjem Choudary and al-Muhajiroun (ALM). This paper challenges assertions of straightforward gender parity between these movements, using field research to evidence the practical ways in which extreme activists understand, interpret, perform, and enact ideology and ideals. It outlines: the ways in which gender produces tensions and fragmentations in the radical right scene; the diversity of masculinities evident in both movements; and the ways in which feminisms are co-opted and women's roles and rights celebrated in the movements. It adds nuance to existing studies of gender in ideology; and through study of practice, reveals some dissimilarities in gender between the movements. Importantly, the contribution of this paper, is that it also exposes the ways in which the practical exigencies of group participation and daily action undercut group ideals.

The paper considers how much participants adhere to an ideological gender binary, with rigid and essentialized roles for women and men, and the ways in which that is disrupted in practice. Through a granular approach to the U.K. extreme scene, this study reveals the ways in which class, race, faith and gender intersect in participants' narratives, and reveal the complexities of their participation. It explores the ways that extreme identities are forged in the intersections of subordinated race, class and gender. In these liminal spaces, in which multiple subordinate identities overlap, extremist activism is born. The paper argues that while the two movements share some gendered features, there are parameters to what they have in common. It begins with a discussion of the difficulties inherent in the study of extremsim, and in particular, gendered extremism, and presents a brief methodology. The next section presents the findings, in three parts: first, it explores gendered fragmentation in the radical right, and the various contradictory gender narratives emergent from 'influencers', as well as the wider activist scene; second, the paper engages with the network linked to alMuhajiroun, referencing Anjem Choudary, the sole Islamist influencer interviewed, and the Islamist network linked to him. This includes members of his inner circle, as well as those on the peripheries, linked in for example via social media. Finally, I 
discuss the significance of the findings and their importance for a nuanced counterterrorism and counter-extremism approach.

Gender is the guiding framework for this piece. Too often, security studies has either ignored the role of gender, or understood gender as synonymous with women. Gender is not just about women. It concerns power, masculinities, norms and how these entwine; it is, as Scott writes, "a way of referring to the social organization of the relationship between the sexes." It is also, this article suggests, an appropriate approach to the two movements studied, given that they are- particularly in the public space - notably homosocial.

\section{Part I: Extremism and Gender: A Fundamental Relationship?}

A great many authors have by now written on gender in extremism, particularly within the far right, and Islamism. Scholarship has tended to discussion of gender in extremism - and particularly extremist ideology - in two distinct ways: first, on women, and second, in a separate body of literature, through a consideration of masculinities. Existing work has found similarities. It has noted the relative dominance of men in both movements; the reliance of both on gender binaries, in roles and in ideology; the use of violent groups to assert particular forms of masculine status; and the agency of women in supporting both violence and anti-feminist themes in jihadist and far right groups.

Studies of gender in Islamist and in particular jihadist groups have tended to exploration of women's roles and agency, noting that long-standing essentialist assumptions that women are not involved in jihad are incorrect. Research has evidenced the support many women have for violent Islamist groups, and their roles within them, whether fund-raising, propagandizing, traveling to join Daesh, fighting (more rarely) and carrying out suicide bomb attacks. ${ }^{9}$ There is also work which engages with the structural constraints on women, and the patriarchal nature of jihadist ideology, noting the ways in which jihadist groups construct and mobilize a binary gendered logic, and the according separation of men's and women's roles. ${ }^{10}$ Additionally, Lahoud has noted the ways in which women are excluded from jihad, in spite of theology. ${ }^{11}$ This does not mean they do not promote violence, however, often shaming men into action. ${ }^{12}$

Similarly, those working on women's roles in the far right, have outlined the possibilities for women joining white supremacist, Nazi and radical right groups - despite the homosociality of such groups - and their findings mirror those above. While fewer in number, and often without leadership powers, many far right women embrace roles of domesticity, what Hardisty termed "kitchen sink activism." ${ }^{33}$ Nationalist movements have long constructed violence around dichotomies of insider/outsider, masculine/feminine, the masculine/male always read as superior to and protective of the feminine/ women. ${ }^{14}$ Feminist scholars have emphasized the ways in which states have used such binaries to go to war, invoking mythic characters across a variety of global contexts, Marianne in France for instance, or Britannia in Great Britain. ${ }^{15}$ The vulnerable and protected woman is necessary to preserve men's 'protector' status. ${ }^{16}$

One key complexity of work on gender and the far right is the terminology used. A diverse array of groups are frequently referred to as 'far right', however, they do not 
uniformly share features and can take positions across a spectrum of beliefs. Gendered ideology is not uniform, an important consideration when attempting to generalize more broadly from findings with any one group, or when seeking to use literature on gender in one subsection of the movement, to better understand another. Indeed, Spierings and Zaslove regard anti-Islam(ism) and the so-called 'counter-jihad' movement opposing Islam as incorporating two contradictory gendered ideologies: traditional gender narratives of historical extreme right groups locating the honor of the nation in its women, in tension with narratives of Western gender equality and freedoms for gay people. Both narratives are used as evidence of Western cultural superiority over Islam and its perceived norms. ${ }^{17}$ Lange and Mügge distinguish between these two positions, labeling them 'nationalist' and 'neo-liberal'. ${ }^{18}$ This problematizes claims that antiIslam(ist) groups on the radical right are a straightforward continuation of fascism, for instance, as Feldman suggests, that the EDL is 'old wine in new bottles'.

In mostly separate work, authors have also considered masculinities in extremism, employing masculinities theorist Connell's most powerful concept: hegemonic masculinity. Hegemonic masculinity is an aspirational masculinity, positioned relative to other subordinate or marginalized masculinities; the concept emphasizes the core feature of masculinities, which is that they are relational. ${ }^{19}$ Gendered identities are socially constructed within a matrix of masculinities and femininities. ${ }^{20}$ Authors have engaged with work on masculinities on the far right for some years, noting the ways in which this can be a homosocial scene, embodying masculinist cultures. $^{21}$ Scholarship has outlined the ways in which themes of globalization, or of personal and collective emasculation inform raced and classed identities in the mobilization toward white supremacist groups. ${ }^{22}$ This is often framed with reference to a 'crisis' of masculinity, seen in shifting global gender norms postglobalization, which are resisted by white men who perceive themselves losing power. ${ }^{23}$ However, Busher cautions against simplistic understandings of the function of masculinity in study of the radical right; even where assertions of "angry, white, damaged and vulnerable" men contain a "kernel of truth", blanket assumptions are not justified. ${ }^{24}$ Additionally, authors have also outlined the ways in which masculinities are not the sole province of men, but are performed by women too. ${ }^{25}$

Growing numbers of authors are using masculinity studies to study jihadist extremism, exploring the effects of gender as a series of power relations. ${ }^{26}$ For instance, authors including Popovski, Aslam, Duriesmith, Ismail, Messerschmidt, Rohde, Sageman and Hegghammer have discussed the importance and variety of jihadist masculinities across global contexts. ${ }^{27}$ Here intersectionality is crucial in recognizing that racialized, gendered and classed identities are produced through power hierarchies. ${ }^{28}$ In particular, gender produces cultures, actions and symbolic practice, what Bourdieu termed 'habitus'. It is through habitus that members of the same social field - such as the radical right or jihadist groups - recognize their actions as having shared meaning. ${ }^{29}$ Employing an intersectional approach, Duriesmith finds gendered jihadist identities are co-constituted in the intersections of global and local discourses and practices. ${ }^{30}$ In his study of Indonesian jihad, for example, Duriesmith evidenced the ways in which global jihadist masculinities both subordinate local masculinities, and provide a means for men in a localized context to achieve status. ${ }^{31}$ 
There is growing academic work addressing these two key movements, the far right and Islamism, together; yet only a few authors have focused on gender. Drawing again on intersectional studies, masculinities author Michael Kimmel advocates gender as a structural approach to consider movements together, enabling exploration of the social relationships co-constituting movements, rather than a 'side-by-side' comparison. ${ }^{32}$ Kimmel's comparative work emphasizes a commonality of masculinities evident in both the far right and Islamism. In another comparison, Mattheis and Winter also note parallels in narratives employed in an identitarian and Daesh narrative. Both ideologies exhibited what the authors term 'gender complementarity' (an essentialist gender binary, asserting opposing and complementary roles for women and men); the shared promotion of the 'domestic ideal' for women; and the shared assertion of patriarchy as a path to societal stability. ${ }^{33}$ Authors including Ebner and Smith have also suggested extremists of both movements mirror one another, in terms of gender binaries and ideology, or 'toxic masculinity'. 34

Despite this growing work the relationship between extremism and broader understandings of gender remains underexplored. In particular, this study aims to address the lack of comparative research between movements. This paper's contribution is its empirical exploration of extremist group members' real-world understandings and interpretations of ideology, exposing the gendered tensions between the two. Additionally, it considers the intersections between structure and agency, masculinities and ideology and the activities of individual activists, as related in a series of interviews and field research. It therefore engages with the holistic function of gender in shaping the actions of both men and women together. This is particularly important if, as authors including Ezekiel suggest, movements are dominated by masculine cultures; one aim here, therefore, is to explore how gender creates cultures and shapes behaviors, potentially limiting or enabling the participation of women, and men. This allows the piece to consider the points of divergence between groups in gender norms and actions, rather than the points of similarity.

\section{Groups Studied}

One of the key purposes of this research was to consider the degree to which assertions of parity in the gendered ideologies of two distinct and opposing ideologies - the U.K.'s radical right and an Islamist network linked to al-Muhajiroun - are justified. I selected these two movements for three reasons: firstly, they represent the key extremist movements recognized in the U.K. currently; secondly, because theories of cumulative extremism assert a causal and reciprocal relationship between them, ${ }^{35}$ although this was not evidenced here; thirdly, because authors are increasingly suggesting that gender is at the heart of any reciprocity in their relationship, although there are few gendered studies of either group within the U.K. ${ }^{36}$ Additionally, the British Government has applied an extremism framework to both, transposing key gendered assumptions about Islamism - men as key risks, women as potential allies - to responses to the far right. However, the U.K.'s definition of extremism is highly contested, and it was therefore important not to assume the equivalence of their behaviors, beliefs or the risks posed, particularly, this article argues, in terms of gender. 
Many terms are used for those active against Islam - the counter-jihad, far right, altright, radical right. Here, the core selection criterion for the first movement was active opposition to Islam(ism); therefore, following Pilkington, I employ the labels antiIslam(ist) and radical right for these activists. Within the U.K.'s anti-Islam(ist) radical right, the English Defence League (EDL) is a key group, and features in the research underlying this paper. A number of participants identified with the EDL, which was founded in 2009 by Stephen Yaxley-Lennon, also known as Tommy Robinson, as a selfdeclared working-class street movement with a "single-issue" focus, to oppose "global Islamification". ${ }^{37}$ In 2011, another anti-Islam(ist) group, Britain First (BF), was founded as a registered political party, with a claimed Christian identity. BF's policy is to "disbar followers of the Islamic ideology from holding public office", and to deport or imprison "anyone found to be promoting the ideology of Islam." ${ }^{38}$ Radical right participants supported these as well as a variety of other groups, often moving between groups.

The second movement studied is al-Muhajiroun, which of the various British Islamist groups, has been a key government concern. Associates have traveled to join Daesh, or had their passports removed to prevent them from doing so. Indeed, the U.K.'s 2018 CONTEST strategy notes the alignment of al-Muhajiroun and Daesh ideology. ${ }^{39}$ The British security services have identified 500 active investigations into 3,000 individuals, with a further 20,000 people who may pose a security risk due to their endorsement of Daesh as a brand. ${ }^{40}$ In 2004, al-Muhajiroun in the U.K. officially disbanded, and since 2006 it is a legally proscribed group under this and under names. ${ }^{41}$ ALM supporters are ready to use violence, if necessary, but are restricted by the 'Covenant of Security', prohibiting violence against citizens of the country they reside in. ${ }^{42}$ In November 2019, however, a man with links to ALM killed two people in a terror attack in London. ${ }^{43}$ Numerous authors have also linked ALM to trans-national terror plots. ${ }^{44}$ In 2000, a British man linked with Omar Bakri Mohammed and ALM, Mohammed Bilal, carried out a suicide attack in Kashmir, killing ten. ${ }^{45}$ In September 2016 al-Muhajiroun leaders Anjem Choudary and Mizanur Rahman (known as Abu Baraa) were jailed for support of Daesh. In 2018 they were released on license.

\section{Methodology}

This paper is based on qualitative research which took place from May 2016 to February 2018 and involved some 18 months of attending demonstrations, street dawah, formal meetings, trials, people's homes; as well as meeting in cafés and talking on the phone. Of the 31 participants, 17 were active within the anti-Islam(ist) scene (six women and $11 \mathrm{men}$ ), and 14 linked to British Islamism (four women and ten men). Some 67 formal interviews were conducted with participants identified as active in groups understood as 'extreme' in the U.K.: the EDL, BF and ALM, and associated networks. Informal interviews also took place with many others linked to the scenes. Transcripts were coded in Atlas $\mathrm{Ti}$, according to gendered themes.

This is therefore a small sample study, yet includes important leadership figures described as 'influencers' in the piece (Anjem Choudary, Jayda Fransen, Tommy Robinson and Anne Marie Waters). Influencers consented to identification; however, other participants are given pseudonyms. All participants were made aware that we 
could not discuss criminal behavior, including the support of Daesh. This clearly limited some discussion. Five of the men were jailed during the research period, for: a plot in support of Daesh (Ahmed), allegiance to Daesh (Anjem Choudary), breach of an ASBO (Mo), funding terrorism (Zakir) and contempt of court (Tommy Robinson). Jayda Fransen was jailed for religiously aggravated harassment. ${ }^{46}$ Adam was charged with downloading Daesh materials.

As noted at the outset of this piece, gender is the guiding framework for the methodology. This entailed an 'empathetic' ethnographic feminist approach of active listening, also increasingly advocated by terrorism scholars such as Dolnik. ${ }^{47}$ This is politically complex, given it produces an analysis which emphasizes primary source material, and the voices and experiences of 'extreme' participants as those with "a privileged window into their motivations". ${ }^{48}$ I include transcript material that is indicative of the views of the movements explored, and therefore offensive to many. I include transcript because 'close-up' research aims to critically reproduce voices often unheard, however 'distasteful' or 'repugnant', in order to interrogate and understand them. ${ }^{49}$ I do not share participants' political views, and we frequently challenged one another on current affairs and other issues.

\section{Part II: Findings}

The gendered analysis of interviews developed here reveals the two movements do mirror one another, but only to a limited extent. Both movements share a complex relationship with feminism, with participants both contesting and reclaiming its meaning. Strategies used to uphold fundamentally patriarchal belief systems are rebranded as furthering female agency. The range of masculinities accepted within both movements is also perhaps broader than suggested in literature which emphasizes hyper-masculinity, toxicity and violence. ${ }^{50}$ However, there are differences. Attitudes toward men's and women's roles are not uniform in the radical right scene, leading to movement fragmentation. Ideology also has a different gendered function in each. Learning and knowledge endow masculine status in the Islamist scene, yet not in the radical right.

In dealing with the Islamist analysis, only one influencer is included, (Choudary) and sections are therefore thematic. First, however the paper considers gender in the antiIslam(ism) scene. It begins with exploration of the ideology of three named leaders/ influencers, before moving to the beliefs of wider grassroots activists, who are anonymized.

\section{Anti-Islam(Ism): Fragmentation in Influencer Belief and Action}

Three radical right influencers participated in the research: Tommy Robinson (EDL and independent), Anne Marie Waters (For Britain) and Jayda Fransen (then Britain First). Importantly, their stances clearly differ from Islamist gender ideals, first and foremost because of the open visibility of women as leaders in the radical right movement. While these three influencers share a gendered understanding of Islam as threat, they represent three different gendered responses to this, constructed through class, sexuality and ethnicity. These constitute: a nationalist, working-class muscular masculinity, to which 
other masculinities, particularly liberal white and Muslim masculinities are subordinated (Robinson); a claimed Christian opposition to the gendered abuses of Islam as false faith (Fransen); and an explicit assertion of women's and gay rights (Waters). Pilkington has argued that the EDL, “... although sharing with more extreme right movements an ultra-patriotic agenda, and being populist in its claims to promote the concerns of 'ordinary people' . . does not uphold an ideology of racial supremacy and promotes women's and LGBT rights". This is important in the wider movement, as the broad assertion of secular values including gender equality, across influencer narratives reshapes the complexion of gender in activism. While each influencer is preoccupied with themes of race, gender and class, these discourses intersect in specific ways, revealing core differences between the groups, their methods and their likely appeal.

There are nonetheless shared themes they share. The three influencers share the assertion of Islam as an unassimilable ideology, and in gendered terms, citing perceived unequal gender relations, patriarchal abuses, and the oppression of women, including as, Fransen suggests, "taking child brides and sex slaves". They frame Islam not as a valid religion but an 'ideology' seeking to subvert and threaten democracy, and in gendered ways. All anti-Islam(ism) participants believe instances of the abuse of young working-class women by predominantly Pakistani-heritage British men were ignored because of institutional political correctness, which does not see class, only race. Consistent with traditional nationalist ideology, all believe the state has a duty to protect 'its' women, defined in racial and cultural terms.

They believe the state has favored immigrant Muslim populations who are sexually predatory. In a speech for Pegida in Dresden in October 2016 Robinson for example stated, "Our women and children need the protection that only a strong moral society can provide. The terrorizing of our women in towns and cities must stop... Europe must and can remain free from the inhumanity of Islam.." ${ }^{51}$ Robinson situates the ability to protect (particular) women at the heart of his vision of masculinity, and nationalist virtue, "it's honorable to want to protect women." 52 However, as a female leader, a key personal aim, Fransen told me, is to mobilize people to protect not women, but children. She told a crowd of around 200 at a protest in Rochdale, "I've said we hold demos for many different reasons, Shariah law, Mega mosques, FGM - but I can't think of a greater cause than this, our kids, systematically targeted. There is nothing greater than our children." 53 Waters also shares concerns about what she believes are insurmountable gendered differences between immigrant Muslim men and Western Europe, which put women at risk, she believes. The influencers use perceived differences in everyday gendered practices - the habitus - to distinguish in-group from out-group; the degree to which others accept these differences distinguishes 'patriots' from those betraying their in-group.

While framing the threat posed by Islam in similar terms - as gendered, racialized and as existential - the ideological basis of their responses differs, however. The EDL, $\mathrm{BF}$ and For Britain demonstrate the different ways in which discourses of gender and race intersect, and the impact this has on the appeal of these groups. All draw on class narratives to construct the authenticity of their positions. However, they do this in different ways. Robinson uses class to deny his position is essentially ideological, or even political. He characterizes his response as authentic, because it embodies an instinctive, emotional and working-class masculinity, inaccessible to liberal elites. Robinson suggests 
this masculinity was constructed, not through books or ideology, but through his working-class upbringing and habitus, which necessitated the performance of a particular physicality. Projecting the potential to fight was necessary to gain status and avoid victimization, within a working-class environment, he claims. While the reproduction of this masculinity in EDL demonstration succeeded in mobilizing particular working-class men, it therefore also alienated broader audiences. Although EDL demonstration has a reputation for casual violence, Robinson frames the collective demonstrations instead as an expression of masculine vulnerability, "Every demonstration's a cry for help" he told me "But the way we talked and the way I acted - I'm only really appealing to my sort of people." 54 Robinson's is a form of compensatory street masculinity: first, from his perspective, the EDL compensates for the failure of the state as protector; second his patriarchal value system, which casts English men as protectors of English women, obliges him to act on this issue. However, although Robinson's opposition to Islam is consistent with historic nationalist assertions of a defensive masculinity, it also signals vulnerability and a primarily 'authentic' emotional response to the perceived defilement of in-group women.

The two female influencers each take a different gendered approach. Fransen's motivation is found in her claimed active Catholicism, and belief that Islam is 'Satanic'. Fransen takes for granted the masculinity of the BF movement and women's support of this. Yet she prioritizes a different form of white working-class masculinity to Robinson: a militarized, disciplinary vision of activism. She contrasted this with a subordinated pub-going, football-watching masculinity that she associates with indiscipline, inaction and ignorance, and the eventual triumph of Islam. It is the British people - particularly men - and their 'laziness' that Fransen blames for the 'rise of Islam'. She told me, "People ... can't be bothered, they would rather watch football, or go to the pub, or watch the X Factor, or go to Legoland. What happens if you're at Legoland and your children get blown up?" 55 She does not challenge hyper-masculine cultures; instead, she embodies particular masculinities in order to contrast them with other subordinate working-class masculinities, such as at EDL protest. She does this in ways that enable her perceived femininity among supporters to remain intact and which do not disrupt the strong gender binary of the group, which asserts natural male and female difference. As a working-class woman fighting for the children of the nation, Fransen has symbolic value. Indeed, Fransen is frequently framed by fans online as a modern Boadicea, the historic female leader of the native British resistance against the Romans, and a symbol she uses on her website. ${ }^{56}$

Waters' approach is different again. Waters, as a gay woman, supports a 'progressive' secular approach to women's rights, which she sees threatened by Islam. While she described the importance of her working-class background, her rhetoric made explicit appeals to a boundaried feminism excluding Muslims. Her protests included women leaders - one 'Islam Kills Women' event for instance included prominent women politicians from Vlaams Belang, a Flemish radical right group - and this put her in conflict with others on the radical or far right. She frames her ideology as necessary to fill a feminist gap in patriot debate. She told me, “... a lot of opponents of Islam have views that I don't like. Anne Coulter ${ }^{57}$ thinks that women should not be allowed to vote! And she's got company. ... I don't want those ... to be the ones speaking out against Islam." 58 
Waters is the most ideologically committed of the influencers to anti-Islam(ist) activism as a means of protecting women's rights. She found the alt-right social media backlash to women's equality frustrating and had suffered online abuse from men who, as she said, "want us back in the kitchen"59

Considering the influencers, there is no clear gender binary of distinct male/female protected/protector roles, in belief or behavior, no 'old wine in new bottles'. Women's rights do have a key role in discussion. Indeed, masculinities and femininities are not monolithic, but multiple, even within the clearly binary gender systems of the groups. Assertions of gender equality are both co-option and enacted in a fragmented gendered approach. Robinson combines what can be thought of as 'masculinities of vulnerability' alongside a more aggressive and confrontational approach, rejecting intellectualism and favoring 'authentic' masculinity constructed within a working class masculinist context. Fransen meanwhile reproduces confrontational masculine behaviors to prove herself and shame men to action. Such shaming tactics are evident in a range of ideological groups, and employed by male leaders and women activists alike, to encourage male action. ${ }^{60}$ It should also be noted that there are inherent complexities in the idea of masculinities of vulnerability and care in this context, given, as explored in Part I, nationalist groups have long constructed masculinities around the 'protection' of women.

\section{Anti-Islam(Ism): Wider Activism}

Grassroots anti-Islam(ist) participants echo the gendered stance of influencers in the three ways outlined (working-class muscular masculinity; women's reproduction of aggressive masculinities; political assertion of women's rights). As with the influencers, the cooption and incorporation of gender equality norms and women's rights meant the wider movement demonstrated a fluidity of gendered performances. There are clear tensions with historical far right gender tropes and binaries, delineating male and female roles. These tensions are evident in both feminized masculinities (the performance by men of gendered traits historically associated with women and femininity, and denigrated in men, such as care, or vulnerability) and female masculinities (the performance of gendered traits historically associated with men and masculinity, and often denigrated in women, such as aggression, anger, or open confrontation. $)^{61}$

Few grassroots activists had engaged with literature on the subject of Islam, which enabled them to contest the notion that they were ideologically driven, and to reject accusations of Nazism, racism, fascism, or being 'far-right'. Following the findings of Busher, participants instead focus on emotional responses to issues, rather than belief. As with the influencers, there are variations in the cooption of gender, race and class in narratives expressed by the EDL and by Britain First, as participants react in different ways to particular gendered behaviors. The accounts explored here indicate the ways in which radical right activism is produced in the intersections of gendered, raced, classed and faithed identities. This activism both reproduces patriarchy, but offers possibilities for its contestation.

\section{Gendered Tensions: Pro-Women's Rights, anti-Feminism}

The relationship between gender and the radical right is not straightforwardly binary. Men and women's roles are not clearly delineated. Yet gender is fundamentally used to 
construct boundaries between Muslims and non-Muslims. Grassroots anti-Islam(ist) participants, like the influencers, claimed to represent (particular) women's rights in their opposition to Islam. Participants uniformly described Islam as an 'ideology' damaging women and the 'fundamental British value ${ }^{\text {,62 }}$ of gender equality. Georgey, who is in her 30s, previously regularly attended EDL demonstrations. Gender constructed her response to Islam, with perceived gender difference in everyday practices (habitus) in her local space a boundary between Muslims and others. Georgey described how a perceived incompatibility of Islam and women's rights mobilized her, "I see a lot of girls in prams here with hijab on ... just two or three years old. I just despair ... We are allowing society to regress right in front of our eyes and are not doing anything about it." Participants believed gendered aspects of Islam could not be reconciled with British values, and most cited child sexual exploitation and rape as key mobilizing narratives in their activism. Jason told me, "They molest our children, they run us over with lorries, they rape our women, they stab our people." Imagined hyper-sexualized and violent gendered norms constructed the boundary with idealized secular British norms, positioned as progressive and equal. Notional ideas of Islam's sexual norms were used to define the boundaries of 'us' and 'them'.

However, participants did not identify as feminist, and blamed (a notional and monolithic) liberal feminism for a failure to defend nonMuslim British women from Muslim men. They also believed white liberal elites deprioritized the white working-class. For participants, this imagined liberal feminism had disrupted a natural gendered logic, familiar to both nationalist and far right groups: the ability of a narrowly defined 'nation' to defend 'its' women. ${ }^{63}$ However, collective ideals and actual behavior diverged. Participant claims to advocate a women's rights-based agenda were in tension with an explicitly anti-feminist stance. Georgey did not consider herself feminist. She described two tiers of feminists: those fake, self-identifying feminists who appropriate the label to virtue-signal; and those who reject the title entirely, yet mobilize on protecting women from the abuses of Islam. While projecting a women's rights discourse as integral to their activism, participants also expressed anti-feminist norms that they claimed to reject in Islam. The tension between proclaimed beliefs about women's rights and actual attitudes was most evident in conversation with 19-year-old EDL supporter, Iain, who believed gendered inequalities in Islam were not 'British', yet also told me "A woman should stay at home and cook and clean, that's the way I've been brought up." Group rhetoric on gender equality did not always conform with participants' views or lives.

Participants who in fact opposed women's rights nonetheless coopted them in rhetoric and discourse. For instance, Jacek, a professional originally from Poland who identifies with the American alt right, did not believe men and women were equal. $\mathrm{He}$ suggested they were like a lotus (female) and diamond (male). He nonetheless supported women like Waters simply because he disliked liberal feminists ("feminazis") more. However, for Jason, one of the few participants who openly professed to a racial - and racist - rather than cultural nationalism, a more general contempt for liberal values encompassed gender equality itself. It is difficult to reconcile Jason's ideological position with that of Georgey or of Waters. The status of women's rights therefore represented a point of tension, evidence of fragmentation within the anti-Islam(ism) movement as a whole. Participants constructed their gendered stance within the 
intersections of their individual lives, collective ideology, and their interaction with other groups, such as 'liberal elites' or the state. For some women the radical right represented a location for the protection of gender equality, which they felt was endangered by liberal feminism and Islam; for other activists, the scene was a place for the protection of ultranationalist patriarchal ideals and the absolute separation of men's and women's roles. These naturally came into conflict with one another.

\section{Challenging the Binary: 'Caring' Men and Fighting Women?}

As suggested above, the 'traditional' separation of gender roles in the 'old' far right is more complex in the radical right explored here. The rigidly patriarchal ideology of far right tropes is disrupted by the inclusion of a women's equality narrative, and by participant behaviors. This was evident in women's activism. The body is emphasized by Bourdieu as one of the primary sites through which symbolic practice or habitus is communicated. ${ }^{64}$ Within EDL protest, a physically embodied working-class masculinity is a means of communicating shared culture, and ideology. ${ }^{65}$ However, women participants also physically emulated the confrontational working-class masculinities around which Robinson suggested the EDL unified. In the radical right, particularly masculine behaviors were normalized within the groups studied, and the associated practices adopted by women as well as men. This carried some risk of censure for women from others in the movement.

This contestation of straightforward assertions of women as in-need-of-protection was a theme in women's accounts and evidenced the ways gender and class intersected to produce their activism. Hel Gower, former personal assistant to Tommy Robinson, told me it was as important for women to adopt confrontational physicalities and practices as for men, as part of the symbolic repertoire of the movement, communicating a class identity. The perceived denigration of the white working-class as 'second class citizens' in modern British society was a recruitment narrative. ${ }^{66}$ This working-class identity was idealized as "rough and ready", Gower suggested, "I don't think growing up in the East End [of London] ${ }^{67}$ you can be anything else." Georgey also nostalgized working-class identities, including a particular working-class masculinity, which women in the radical right also adopted. It allowed for status gain, and the further subordination of Muslim masculinities. Like other forms of 'lower-class' male violence, this subordination through confrontation was performative. ${ }^{68}$ Georgey for instance said she had challenged Anjem Choudary during street dawah, a confrontation she was particularly proud of as she believed it subverted Muslim gender roles. Georgey had thousands of Twitter followers and regularly contested essentialized gender roles requiring women to accept male protection in the online space, and also trolled social media users defending Islam. Such expressions of female aggression appeared to be both accepted and often praised by men in the homosocial scene.

The incorporation noted by Spierings and Zaslove of two conflicting gendered ideologies into the radical right - traditional patriarchy and progressive gender equality - renders the 'doing' of radical right activism complex, with activist accounts showing the complexity of gender in their behavior. This was evident in the ways in which narratives of gender equality enabled men to reframe traditional 'protector' masculinities as more (feminized) masculinities of care and vulnerability, recognizing and incorporating 
women's agency. For instance, in June 2017, former football hooligan John Meighan staged the first Football Lads Alliance march in London, at which several thousand predominantly male protesters marched against Islamist extremism. Meighan wanted to exploit existing football cultures of masculine working-class protest, but also to appeal to families. In particular, both Meighan and another participant, former EDL activist and football hooligan, Alex, regarded their activism as the manifestation of social conscience, channeling football violence into 'good'. Other male participants also outlined how their involvement in anti-Islam(ist) protest represented a (clearly boundaried to non-Muslims) form of care, through activism aimed at helping the (nonMuslim) homeless, veterans or (nonMuslim) women affected by grooming by particular men. Indeed, activism as shared endeavor gave even violence a moral and educative purpose. They reframed homosocial activism as masculinized forms of care and vulnerability, echoing Robinson's narrative in the previous section, and revealing a more complex - less essentialized - masculinity than the strictly dichotomous gendered logic of the 'old' far right suggests. This allowed them to justify what, essentially, remained highly gendered and racialized activism.

\section{Islamism: Gendered Logics: Gendered Response}

This section considers gender in Islamist belief and behaviors, and the differences between these and the radical right. First, it outlines a more clear-cut essentialism than in the radical right participants, rooted in a stricter adherence to the gender-divided roles set out in Islamist ideology. Indeed, unlike in the radical right, ideology, scholarship and ideological knowledge have a gendered role, endowing particular forms of masculine status. There is also a greater coherence around specific ideological positions among Islamists than for the anti-Islam(ist) activists, who demonstrate a range of gendered activisms. "As Hegghammer has emphasized, ideology is not simply 'belief system', it is 'doctrine and aesthetics"' ${ }^{69}$ Within ALM, this consists of symbolic practices that communicate membership of a shared community. ${ }^{70}$ This means a lack of book learning' is less important than the ability to utilize a particular discourse to be recognized by others as a 'like-mind'. The second part of this section then emphasizes the diversity of masculine performances as symbolic practice that ideology enables, including scholarly and 'caring' masculinities. These, to some degree, are shared with men in the radical right; yet while radical right men emphasize care as a product of class, for the men here, care is linked explicitly to ideology. What is important throughout is that participants construct their extremism in the intersections of the hybridity of their identities: their Islamic knowledge, their response to secularism, and their understanding of gender, particularly relating to sexual norms.

\section{Gender Binaries: Male Warriors and Female Honor}

Gender functions in Islamist ideology to create boundaries. Differences in social and sexual norms were cited by all the participants as a distinct and untraversable boundary between secular society, and the ALM in-group. For leader Anjem Choudary, and consistent with Islamist ideologues such as Qutb, sexual morality and sexual norms marked a barrier between Islam and a corrupt West. The apparent sexual degeneracy of the 
West is, for Choudary, evidence that the underlying principles of the system are incorrect. Secular society has permitted practices which contravene the domestic roles imagined by Qutb for Muslim women. Choudary said, “... for women, living in the West, they are used to exploitation. ... naked women on billboards ... All of this exploitation ... - it would be eradicated in Islam ... where the man and woman are equal before God... [and] women are elevated - they're mothers, they're sisters, they're aunts, they're nieces, they're daughters." ${ }^{71}$ Women and men are fundamentally different, he suggests, and it is "common sense" for men to want primarily to protect them. ${ }^{72}$ This essentialism ensures that it is men who alone have access to the highest status role (warrior) in times of conflict, and women gain status through their relationship with him, "Definitely in Islam, you know, the mujahid [warrior] is a very honorable person. Why should not people [sic] want to get married to people like that? ..- .. very honorable people who sacrifice their lives for what they believe in."73 Choudary also suggested ALM ideology occupies not a different, but a parallel gendered space, in which the mujahid has the high status of a (secular) fireman or soldier. ALM therefore represents a group in which Muslims who do not believe in secularity are able to find equivalent, but more appropriate, masculine roles.

Participants largely adhered to Choudary's vision of the gender binary of separated roles for men and women as both producing a boundary with the (immoral) secular space, and guiding relations within Islam and their own practices. This patriarchal binary, separating roles and ensuring men's protection of women, was firstly evident in my relative lack of access to women activists, and also in women's complete lack of visibility in leadership roles. Women were not at the court cases I attended, nor were they participants in the street dawah that I saw, despite their broader activism within the group. ${ }^{74}$ All of the male participants but Rifat were married, and mainly to women who shared their faith and beliefs, they told me. ${ }^{75}$ Despite numerous requests to meet wives who were fellow activists, the group would not permit this as they regarded women as particularly vulnerable at that time.

Mirroring the mobilization of the radical right around issues of perceived sexual difference and gender norms, Islamist participants were also motivated to ALM activism by opposition to the perceived sexual immorality of secular society. Mo, a convert in his 20s, and part of Choudary's circle, believes women only have rights in Islam. He distinguishes between the passivity of women in Islam, treated as a 'diamond', and their immoral assertiveness elsewhere. Meeting one evening, he described his journey in despair, a woman "... just drunk, out of her face in the street." faith requires a response to such perceived immorality. Faith dictates all action. Faith was not a mask for other issues; it was indistinguishable from them, framed as the only means to enact system change. Rifat for instance told me Islam was about action, "... both public and private [Islam was about] the issue of evil. Rape, drugs, prostitution. Or domestic violence." For Rifat, gendered inequality is a social injustice around which to mobilize faith, according to the gendered binary constructed by ALM. This cohered to cultural ideas of gender difference he described as part of his community habitus growing up. He believed this gendered habitus was incompatible with what he considered to be uniform secular norms. Some of this mobilization of faith was confrontational and hyper-masculine. Mo, for instance, had been involved in so-called 'Muslim Patrol' in an effort to prevent public immorality, confronting people he 
considered to be affronting Islamic morality in public spaces. This led to prison, where, given his 'terrorist' designation, he enjoyed a high masculine status, he told me, with both friends, and acolytes.

\section{Gendered Identities: Binary Blurred?}

While participants were clear on the necessity of a gendered binary, and what Mattheis and Winter term the 'complementarity' of men's and women's roles, ${ }^{77}$ participant behaviors and responses were less clear-cut, and in two ways. First, given they constructed activist identities at the intersections of different social fields to which they belonged, their relationship with 'western feminism' was not straightforward. Two women I spoke to co-opted secular feminist narratives, for instance, even as they also explicitly opposed them. Second, hallowed Islamist protector and 'warrior' or mujahid masculinities permitted what was in practice a range of masculine performance, some feminized. These were positioned as consistent with the internal group ideology.

As in the radical right, participant ideals and action were not consistent. Islamist participants opposed (a monolithic) secular feminism as wrong, and unnecessary, given their belief in Islam as a practice and ideology that enshrines women's rights. Akash explicitly challenged what he termed "western feminism" because he felt it always sought to emasculate men, and blame them for problems between the sexes. Such views were common. However, the few female participants expressed a more complex relationship, drawing on different aspects of their ultimately British identities to produce their adherence to the movement. Saleha, formerly a teenage supporter of Daesh and connected to Choudary's online networks, described her move away from secular feminism as part of her journey to Islamism, "I was one at first [a feminist]. Then I realized it was wrong ... and so I rejected it." However, Saleha went on to suggest her attitude toward Western feminism was a product of social stigma in her wider Muslim community, rather than belief, "If I as a Muslim said I was into feminism, then I would have got so much hate ... you're a slag, you're this, you're supporting British ideology. And

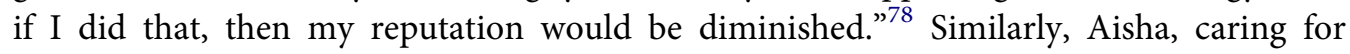
her small children while her husband was in prison for terrorism offenses framed her adherence to Islamism in feminist terms, borrowing from the 'rights' discourse of secularism to do so, "Happily, I say I obey my husband. It doesn't sit well with feminists. But I like to think of myself as a feminist. But maybe not the same type."79 Aisha employed a secular framing of gendered relations, even while rejecting secularism, and used this to emphasize her agency in adopting a relationship of submission toward her husband. Like other Salafi women, Aisha asserts her agency within the strictly gendered practices of her faith. ${ }^{80}$

As Lahoud, and also Pearson and Winterbotham have noted, Islamist narratives can enable women to challenge mainstream (Western) narratives of the meaning of empowerment and subjugation, rendering the terms relative, a question of framing. ${ }^{81}$ Indeed, women constructed their adherence to the ALM network through a prism of race, faith, gender and a British feminism they sought to reject. Additionally, and in a counterpoint to the anti-Islam(ist) depiction of Islam as a site of oppression for women, Rifat suggested ALM functioned as a form of refuge for convert women to escape the patriarchal abuses of secular society, women who were "beaten by brothers and fathers, 
their faith insulted." 82 The reversion of white nonMuslim women to Islam enabled another gender narrative: the superiority of Muslim men, Islamic culture, and Muslim masculinities. Female (particularly white) reverts were symbolically useful to emasculate nonMuslim men. Rifat said, "An EDL guy, he said, you guys love wearing dresses. We said, your wife prefers a Muslim guy rather than one of you." 83 Women's (private) sexual relationships are instrumentalized to prove collective dominance over out-group men. Indeed, this exchange evidences the ways in which both groups instrumentalize women to emasculate the other.

The second way in which the clear gender binary of ALM was disrupted was in the range of roles adopted by men, particularly those demonstrating emotional lability. Hegghammer has noted the importance of displays of sensitivity to jihadist men, and that was evident here. ${ }^{84}$ These displays included both caring and scholarly masculinities, alongside masculinities of vulnerability. Men described being prompted to tears by news footage of abuses of children in Syria, their emotional responses then prompting a desire for action and for learning about the types of appropriate action. While anti-Islam(ist) activists rejected associations with ideology, the acquisition of Islamic knowledge in and of itself gives ALM and networked participants masculine status. When Zakir went on trial for funding terrorism, he described how only knowledge of and adherence to the strict rules of jihad give a fighter the authority of Islam, and honor of being a warrior, rather than a simple killer. Knowledge of key Quranic concepts, the teachings of particular scholars, the rules of violence, as well as that violence itself, all contributed together to the production of a particular masculine status. Yet high status masculinities of violent jihad were both complemented and enabled by masculinities of care and sensitivity. Zakir was mobilized to fund his friend in part because of videos of brutalities against children, he told me, videos he described to me with tears in his eyes. The power of these images is not just the humiliation of Muslim women and children, and the injustice they represent, but in evoking a particular emotional masculinity, which in turn produces warrior masculinities as response. The ultimate aim of this process - violence, for the right reasons - mitigates any potential weakness in tears or sadness.

\section{Part III: Conclusions}

This paper considered the role of gender in constructing belief in the U.K.'s anti-Islam(ism) movement, and in an Islamist network linked to Anjem Choudary and alMuhajiroun. It considered the degree to which participants adhere to an ideological gender binary, with rigid and essentialized roles for women and men, and the degree to which that is disrupted in practice. It provides an empirical account of the realities of group members' understanding of ideological and propaganda narratives, and the ways in which their interpretations and performances puncture or adhere to those discourses. Importantly this exposes the ways in which the practical exigencies of daily action undercut group ideals. It also suggests the co-constitutional and mutually reinforcing relationships between the varied forms of power hierarchies evident in participant interviews, codified by discourses and practices of gender, race and class, amongst other factors. As such it perhaps raises more questions than answers about the fluctuations and differences between groups, and the kinds of contrasting gendered performances evident within them. 
Both movements considered here are homosocial. They have broadly masculinist and patriarchal cultures and habitus, which dictate and limit the ways in men and women can participate. The literature on both suggests they share features: the segregation of complementary gender roles (gender binary); an emphasis on domesticity; and a reverence for patriarchy. This paper shows that there are ways in which the two movements resemble one another, given the patriarchal foundations of both; but it argues against a straightforward reading of activists as embodiments of the same problematic attitudes to women, or gender. There are clear differences between them, and particularly in the anti-Islam(ist) scene, there is great diversity in the gendered approaches of different leaders and groups, and possibilities for women.

There are particular tensions regarding the scope and extent of women's participation. The absence of uniformity is apparent within, as well as between groups. The piece explored the relatively incoherent gendered picture emergent in the radical right. While participants generally adhere to essentialized notions of male and female roles, consistent with historic nationalism, the picture is not clear-cut. Both influencers and to some degree grassroots activists in the radical right participant group demonstrate varying approaches to gender norms and the role of women, echoing the gendered tensions identified by Spierings and Zaslove. ${ }^{85} \mathrm{~A}$ conservative reliance on patriarchal traditional norms aimed at preserving the integrity of the racialized nation, which can be based on Christian ideals, is at odds with a more progressive ideology, highlighting women's rights. ${ }^{86}$ This presents an ideological fracture, around which it is difficult for the various strands of the anti-Islam(ism) scene to unite. The fracture separates a movement such as the EDL from more 'traditionally' far right groups including Britain First, or white supremacists in the United States, or indeed sections of the alt-right. ${ }^{87}$ Some antiIslam(ism) participants do take the notion of women's rights seriously; contrary to Feldman or Jackson, this is not simply 'old wine in new bottles'. ${ }^{88}$

Lange and Mügge have indicated that the role of women in right-wing populist movements is ambiguous and wide-ranging. This is supported here. ${ }^{89}$ Women are found in leadership roles, unlike in the Islamist movement, and they adopt masculine practices and identities; however, this does not mean they contest patriarchal norms. As in other nationalist movements, some women here clearly support patriarchal values. ${ }^{90}$ Women can wield power and adopt masculine behaviors, but to do so risks conflict with dominant masculine and patriarchal values and norms and a degree of censure.

Due to ethical constraints prohibiting discussion of Daesh, conversation with Islamists about belief was difficult. Islamists discussed broader themes, including a binary logic governing gender roles, which they supported. The literature on Islamism notes the ways in which masculinist norms dominate Islamist ideology; ${ }^{91}$ not surprisingly, this is reflected here. Nonetheless, participants constructed their activism not solely around ideology, but in the intersections between ideology and their often hybrid identities. This meant participants' actions and narratives sometimes undercut ideology. Women linked to Choudary's circle, for instance, both contested and reclaimed the meaning of secular feminism, as women and men did in the radical right. Strategies used to uphold fundamentally patriarchal belief systems, central to which is the idea of the male necessity to protect women are rebranded as furthering female agency. This has appeal to both men and women, even if it does not give women power, or challenge patriarchy. 
Considering both movements, the range of masculinities accepted is perhaps broader than suggested in the literature, which emphasizes the importance of violent masculinities to gain status. ${ }^{92}$ However, while a robust and combative masculinity is apparent in both movements, this is complemented by an emotionally labile sensitivity. In both movements, it is clear that where women are active, even as leaders, in the radical right, patriarchal norms and habitus constantly threaten women's participatory powers, on their own terms. Nonetheless, there is no straightforward replication of gender norms across the masculinities in both movements. In particular, 'ideology' has a different cultural role. The 'Sheikh' or male scholar is revered in Islam, and Islamist participants sought to demonstrate learning. This is important to distinguish the virtuous warrior from, as Zakir suggests, a mere killer. It is therefore important for Islamists to display their ideological status through cultural practices, as Hegghammer has noted. ${ }^{93}$ In the anti-Islam(ist) radical right meanwhile, an explicitly ideological position is equated with inauthenticity, and easy accusations of racism. Their activism more closely resembles Busher's finding of support for 'themes' and a deemphasis of strict 'ideology'. ${ }^{94}$

The piece ultimately argues, therefore, that the complementarity of gendered roles in these movements cannot be uniformly assumed, and nor should this assumption underly counter-extremism responses. Additionally, while the radical right and alMuhajiroun networks explored here do share some gendered features, much separates them. In the West, particularly, it is important to recognize that while Salafi-jihadist ideology opposes secular gendered national values, in practice, individuals also appear to incorporate these to some degree, because they are British. Meanwhile, radical right ideologies and practices are often shared with national institutional values, and historical assertions of identity. The different positionality of each movement relative to mainstream and state gendered discourses is a crucial distinction. Recognition of this is particularly important, because different forms of extremism require tailor-made counter-extremism responses. Policy to counter the far right is unlikely to work if it simply replicates that used against Islamist extremism. ${ }^{95}$

\section{Notes}

1. Britain First, "MISSION STATEMENT," March 5, 2015, http://www.britainfirst.org/ mission-statement/.

2. Charlie Winter, "Women of the Islamic State" (The Quilliam Foundation, 2015), http:// www.quilliamfoundation.org/wp/wp-content/uploads/publications/free/women-of-the-islamicstate3.pdf; Elizabeth Pearson, "Wilayat Shahidat: Boko Haram, the Islamic State, and the Question of the Female Suicide Bomber," in Boko Haram: Behind the Headlines, ed. Jason Warner and Jacob Zenn (CTC Sentinel, 2018); Ashley A Mattheis and Charlie Winter, "The Greatness of Her Position':" (International Centre for the Study of Radicalisation and Political Violence, 2019).

3. V. Spike Peterson, "Gendered Nationalism," Peace Review 6, no. 1 (March 1, 1994): 83, https://doi.org/10.1080/10402659408425777.

4. Vikram Dodd and Jamie Grierson, "Fastest-Growing UK Terrorist Threat Is from Far Right, Say Police," The Guardian, September 19, 2019, sec. UK news, https://www.theguardian. com/uk-news/2019/sep/19/fastest-growing-uk-terrorist-threat-is-from-far-right-say-police.

5. Vikram Dodd Police and crime correspondent, "MI5 to Take over in Fight against Rise of UK Rightwing Extremism," The Guardian, October 28, 2018, sec. UK news, https:// 
www.theguardian.com/uk-news/2018/oct/28/mi5-lead-battle-against-uk-rightwing-extremistspolice-action.

6. Joan Smith, Home Grown: How Domestic Violence Turns Men Into Terrorists (London: riverrun, 2019); Joan Smith, "How Toxic Masculinity Is Tied to Terrorism," UnHerd, May 16, 2019, https://unherd.com/2019/05/how-toxic-masculinity-is-tied-to-terrorism/; David Lammy, "Islamists, Gangs, the EDL - All Target Alienated Young Men," The Guardian, May 24, 2013, sec. UK news, http://www.theguardian.com/uk/2013/may/24/islamists-gangsedl-target-young-men; Sarah Malik, "A 'sick, Broken" Masculinity Is Fuelling Extremism, Says Documentary Maker," Topics, September 7, 2018, https://www.sbs.com.au/topics/life/ culture/article/2018/09/06/sick-broken-masculinity-fuelling-extremism-says-documentary-maker; Diane Abbott, "Britain's Crisis of Masculinity" (Demos Twentieth Birthday Lecture, London, 2013).

7. For work asserting some form of similarity between certain groups see Mattheis and Winter, “The Greatness of Her Position':"; Julia Ebner, The Rage: The Vicious Circle of Islamist and Far-Right Extremism (London; New York: I.B.Tauris \& Co., 2017), https:// www.amazon.co.uk/Rage-Vicious-Islamist-Far-Right-Extremism-ebook/dp/B0746HD6R6/ref= sr_1_2?ie=UTF8\&qid=1527613467\&sr=8-2\&keywords=the+rage; Michael Kimmel, Healing from Hate: How Young Men Get Into-and Out Of-Violent Extremism, First edition (Oakland, California: University of California Press, 2018); Smith, Home Grown.

8. Joan Scott, "Gender: A Useful Category of Historical Analysis," The American Historical Review, 91, no. 5. (Dec., 1986): 1053-1075.

9. Mia Bloom, Bombshell: The Many Faces of Women Terrorists (C Hurst \& Co Publishers Ltd, 2011); Swati Parashar, "Gender, Jihad, and Jingoism: Women as Perpetrators, Planners, and Patrons of Militancy in Kashmir," Studies in Conflict \& Terrorism 34, no. 4 (March 16, 2011): 295-317, https://doi.org/10.1080/1057610X.2011.551719; Katharina Von Knop, "Women in Religious Terror Organizations," in Strategic Intelligence: Volume 1, Understanding the Hidden Side of Government, ed. Loch K. Johnson, vol. I (Westport, Conn: Praeger, 2006), 154-77; Pearson, "Wilayat Shahidat: Boko Haram, the Islamic State, and the Question of the Female Suicide Bomber"; Katherine E Brown, "Gender and Counter-Radicalization: Women and Emerging Counter-Terror Measures," in Gender, National Security and Counter-Terrorism, ed. Jayne Huckerby and Margaret L. Satterthwaite (Abingdon, Oxon; New York: Routledge, 2013); Charlie Winter and Devorah Margolin, "The Mujahidat Dilemma: Female Combatants and the Islamic State," CTC Sentinel 10, no. 7 (August 2017), https://ctc.usma.edu/v2/wp-content/uploads/2017/08/CTC-Sentinel_ Vol10Iss7.pdf; Winter, "Women of the Islamic State."

10. Pearson, "Wilayat Shahidat: Boko Haram, the Islamic State, and the Question of the Female Suicide Bomber"; Kiriloi Ingram, "IS's Appeal to Western Women: Policy Recommendations" (International Centre for Counter-Terrorism, The Hague, 2017), https:// icct.nl/publication/iss-appeal-to-western-women-policyrecommendations/.

11. Nelly Lahoud, "The Neglected Sex: The Jihadis' Exclusion of Women From Jihad," Terrorism and Political Violence, no. August (February 2014): 1-23, https://doi.org/10.1080/ 09546553.2013.772511; Nelly Lahoud, "Can Women Be Soldiers of the Islamic State?," Survival 59, no. 1 (January 2, 2017): 61-78, https://doi.org/10.1080/00396338.2017.1282675.

12. Bloom, Bombshell; Elizabeth Pearson, "Online as the New Frontline: Affect, Gender, and ISIS-Take-Down on Social Media," Studies in Conflict \& Terrorism 0, no. 0 (July 7, 2017): 1-25, https://doi.org/10.1080/1057610X.2017.1352280.

13. Hilary Pilkington, "EDL Angels Stand beside Their Men ... Not behind Them': The Politics of Gender and Sexuality in an Anti-Islam(Ist) Movement," Gender and Education 29, no. 2 (February 23, 2017): 238-57, https://doi.org/10.1080/09540253.2016.1237622; Kathleen M. Blee and Kimberly A. Creasap, "Conservative and Right-Wing Movements," Annual Review of Sociology 36, no. 1 (2010): 269-86, https://doi.org/10.1146/annurev.soc. 012809.102602; Kathleen M. Blee, "Becoming A Racist: Women in Contemporary Ku Klux Klan and Neo-Nazi Groups," Gender \& Society 10, no. 6 (1996): 680-702, https://doi.org/10. 1177/089124396010006002; Kathleen M. Blee and Sandra McGee Deutsch, "Introduction," 
in Women and the Right: Comparisons and Interplay Across Borders (Penn State University Press, 2012), 1-17, http://muse.jhu.edu/chapter/491433; Cynthia Miller-Idriss and Hilary Pilkington, "Women Are Joining the Far Right - We Need to Understand Why | Cynthia Miller-Idriss and Hilary Pilkington," The Guardian, January 24, 2019, sec. Opinion, https:// www.theguardian.com/commentisfree/2019/jan/24/women-far-right-gender-roles-radical-rightmigrant-muslim.

14. Peterson, "Gendered Nationalism," 83; Mrinalini Sinha, "Gender and Nation," in Feminist Theory Reader, ed. Carole Mccann and Seung-kyung \& Kim (Routledge: London, 2004), 227-243.

15. For a discussion of this, and of other authors making this point see Ashley Mattheis, "Shieldmaidens of Whiteness: (Alt) Maternalism and Women Recruiting for the Far/AltRight," Journal for Deradicalization 0, no. 17 (December 23, 2018): 128-62.

16. K. Hutchings, "Making Sense of Masculinity and War," Men and Masculinities 10, no. 4 (September 2007): 389, https://doi.org/10.1177/1097184X07306740; Jean Bethke Elshtain, Women and War (University of Chicago Press, 1987), 9; Véronique Pin-fat and Maria Stern, "The Scripting of Private Jessica Lynch," Alternatives: Global, Local, Political 30, no. 1 (2005): 45, https://doi.org/10.1177/030437540503000102; Joshua S. Goldstein, War and Gender: How Gender Shapes the War System and Vice Versa, New Ed edition (Cambridge: Cambridge University Press, 2003), 262-66.

17. Niels Spierings and Andrej Zaslove, "Gendering the Vote for Populist Radical-Right Parties," Patterns of Prejudice 49, no. 1-2 (March 15, 2015): 143, https://doi.org/10.1080/ 0031322X.2015.1024404.

18. Sarah L. de Lange and Liza M. Mügge, "Gender and Right-Wing Populism in the Low Countries: Ideological Variations across Parties and Time," Patterns of Prejudice 49, no. 1-2 (March 15, 2015): 62 \& 79-80, https://doi.org/10.1080/0031322X.2015.1014199.

19. Raewyn W. Connell, Masculinities, 1st Revised (Cambridge: Polity Press, 2005); Raewyn W. Connell, Gender and Power: Society, the Person and Sexual Politics (Cambridge, UK: Polity Press, 1987); Raewyn W. Connell and James W. Messerschmidt, "Hegemonic Masculinity: Rethinking the Concept," Gender \& Society 19, no. 6 (December 2005): 829-859, https://doi. org/10.1177/0891243205278639.

20. Judith Butler, Gender Trouble: Feminism and the Subversion of Identity, New edition (New York: Routledge, 2006); Big Think, Judith Butler: Your Behavior Creates Your Gender, 2011, https://www.youtube.com/watch?v=Bo7o2LYATDc; Hutchings, "Making Sense of Masculinity and War."

21. Pilkington, "EDL Angels Stand beside Their Men ... Not behind Them"; RAPHAEL S. EZEKIEL, "An Ethnographer Looks at Neo-Nazi and Klan Groups: The Racist Mind Revisited," American Behavioral Scientist 46, no. 1 (September 1, 2002): 51-71, https://doi. org/10.1177/0002764202046001005.

22. Matthew Goodwin, "The Roots of Extremism: The English Defence League and the Counter-Jihad Challenge," Briefing Paper (Chatham House, 2013), http://www. chathamhouse.org/sites/files/chathamhouse/public/Research/Europe/0313bp_goodwin.pdf; J. Treadwell and J. Garland, "Masculinity, Marginalization and Violence: A Case Study of the English Defence League," British Journal of Criminology 51, no. 4 (April 2011): 621-634, https://doi.org/10.1093/bjc/azr027; Jon Garland and James Treadwell, "No Surrender to the Taliban!': Football Hooliganism, Islamophobia and the Rise of the English Defence League," in Papers from the British Criminology Conference 2010, 2010, Vol.10, Pp.19-35., vol. 10 (British Criminology Conference, British Society of Criminology, 2010), 19-35, http://www. britsoccrim.org/v10.htm http://hdl.handle.net/2381/8966; M. Kimmel, "Racism as Adolescent Male Rite of Passage: Ex-Nazis in Scandinavia," Journal of Contemporary Ethnography 36, no. 2 (April 2007): 202-218, https://doi.org/10.1177/0891241606298825; Kimmel, Healing from Hate.

23. Michael S. Kimmel, "Globalization and Its $\mathrm{Mal}(\mathrm{e})$ Contents: The Gendered Moral and Political Economy of Terrorism," International Sociology 18, no. 3 (September 2003): 603-620, https://doi.org/10.1177/02685809030183008; Malik, “A ‘sick, Broken” Masculinity 
Is Fuelling Extremism, Says Documentary Maker"; Diane Abbott, "Britain's Crisis of Masculinity," https://www.demos.co.uk/files/DianeAbbottspeech16May2013.pdf.

24. Joel Busher, The Making of Anti-Muslim Protest: Grassroots Activism in the English Defence League (London; New York, NY: Routledge, 2015), paras. 51-2.

25. Jack Halberstam, Female Masculinity, 1 edition (Duke University Press Books, 2012); Chris Beasley, Gender and Sexuality: Critical Theories, Critical Thinkers, 1 edition (London; Thousand Oaks, Calif: SAGE Publications Ltd, 2005).

26. Butler, Gender Trouble; Marysia Zalewski, "Do We Understand Each Other Yet? Troubling Feminist Encounters With ( In )" 9 (2007): 302-312, https://doi.org/10.1111/j.1467-856x. 2007.00287.x; Laura Sjoberg, Gendering Global Conflict: Toward a Feminist Theory of War (New York: Columbia University Press, 2013).

27. Marc Sageman, Leaderless Jihad: Terror Networks in the Twenty-First Century, 1st edition edition (Philadelphia: University of Pennsylvania Press, 2008); Edited by Thomas Hegghammer, "8. Non-Military Practices in Jihadi Groups," in Jihadi Culture: The Art and Social Practices of Militant Islamists (Cambridge, United Kingdom: Cambridge University Press, 2017), 171-220; David Duriesmith, "Hybrid Warriors and the Formation of New War Masculinities: A Case Study of Indonesian Foreign Fighters," Stability: International Journal of Security and Development 7, no. 1 (2018), https://doi.org/10.5334/sta.633; David Duriesmith and Noor Huda Ismail, "Militarized Masculinities beyond Methodological Nationalism: Charting the Multiple Masculinities of an Indonesian Jihadi," International Theory 11, no. 2 (July 2019): 139-59, https://doi.org/10.1017/S1752971919000034; James W. Messerschmidt and Achim Rohde, "Osama Bin Laden and His Jihadist Global Hegemonic Masculinity," Gender \& Society 32, no. 5 (October 1, 2018): 663-85, https://doi.org/10.1177/ 0891243218770358; Vesselin Popovski and Maleeha Aslam, Gender-Based Explosions: The Nexus Between Muslim Masculinities, Jihadist Islamism and Terrorism (Tokyo: United Nations University Press, 2012).

28. Kimberle Crenshaw, "Demarginalizing the Intersection of Race and Sex: A Black Feminist Critique of Antidiscrimination Doctrine, Feminist Theory and Antiracist Politics," The University of Chicago Legal Forum 140 (1989): 139-167; Jelke Boesten, Sexual Violence During War and Peace: Gender, Power, and Post-Conflict Justice in Peru (New York, UNITED STATES: Palgrave Macmillan, 2014), http://ebookcentral.proquest.com/lib/kcl/ detail.action?docID=1699326; Hae Yeon Choo and Myra Marx Ferree, "Practicing Intersectionality in Sociological Research: A Critical Analysis of Inclusions, Interactions, and Institutions in the Study of Inequalities," Sociological Theory 28, no. 2 (June 1, 2010): 129-49, https://doi.org/10.1111/j.1467-9558.2010.01370.x.

29. Bourdieu cited in Anthony King, "Thinking with Bourdieu Against Bourdieu: A 'Practical' Critique of the Habitus," Sociological Theory 18, no. 3 (November 1, 2000): 419-20 \& 424, https://doi.org/10.1111/0735-2751.00109.

30. Bridget Fowler, "Reading Pierre Bourdieu's Masculine Domination: Notes Towards An Intersectional Analysis of Gender Culture and Class," Cultural Studies 17, no. 3-4 (2003): 468-94; Raewyn Connell, "Masculinity Research and Global Society," in Analyzing Gender, Intersectionality, and Multiple Inequalities: Global, Transnational and Local Contexts, ed. Esther Ngan-Ling Chow, Marcia Texler Segal, and Lin Tan, vol. 15 (Emerald Group Publishing Limited, 2011), 51-72, http://www.emeraldinsight.com/doi/pdfplus/10.1108/ S1529-2126\%282011\%290000015008; Lori Handrahan, "Conflict, Gender, Ethnicity and Post-Conflict Reconstruction," Security Dialogue 35, no. 4 (December 1, 2004): 429-45, https://doi.org/10.1177/0967010604049521.

31. Duriesmith, "Hybrid Warriors and the Formation of New War Masculinities: A Case Study of Indonesian Foreign Fighters."

32. Kimmel, Healing from Hate, $\mathrm{x}$.

33. Mattheis and Winter, "The Greatness of Her Position':"

34. See Ebner, The Rage: The Vicious Circle of Islamist and Far-Right Extremism.

35. Consideration of these terms will follow 
36. Pilkington's work on the EDL is an exception. Recent work on ALM had not explored gender, or women.

37. Hilary Pilkington, Loud and Proud: Passion and Politics in the English Defence League (Manchester University Press, 2016), 37-38, http://www.oapen.org/search?identifier=607920.

38. 'Policy Debates', Britain First Literature, AGM 3 December 2016

39. Home Office, "CONTEST: The United Kingdom's Strategy for Countering Terrorism" (London: The Home Office, June 2018), 19.

40. Telegraph Reporting Team, "23,000 People Have Been 'subjects of Interest' as Scale of Terror Threat Emerges after Manchester Attack," The Telegraph, May 27, 2017, 000, http://www. telegraph.co.uk/news/2017/05/27/23000-people-have-subjects-interest-scale-terror-threat-emerges/.

41. Kylie Connor, "Islamism' in the West? The Life-Span of the Al-Muhajiroun in the United Kingdom," Journal of Muslim Minority Affairs 25, no. 1 (April 1, 2005): 119, https://doi.org/ 10.1080/13602000500114124; Home Office, "PROSCRIBED TERRORIST ORGANISATIONS,” Policy Paper (London: UK Goverment, July 12, 2013), https://assets. publishing.service.gov.uk/government/uploads/system/uploads/attachment_data/file/795457/ Proscription_website.pdf.

42. Innes Bowen, Medina in Birmingham, Najaf in Brent: Inside British Islam (London: C Hurst \& Co Publishers Ltd, 2014), 68.

43. Staff Writer, "Usman Khan Profile: Terrorist Who Wanted to Bomb London Stock Exchange," The Guardian, November 30, 2019, sec. UK news, https:/www.theguardian.com/uk-news/2019/ nov/30/usman-khan-profile-terrorist-who-wanted-to-bomb-london-stock-exchange.

44. Interview, Anjem Choudary, 18 July 2016

45. Hope Not Hate, "Al-Muhajiroun Network," The Hate Files, Hope Not Hate, 2013, http:// www.hopenothate.org.uk/research/the-hate-files/al-muhajiroun-network/; Emma Brockes, "British Man Named as Bomber Who Killed 10," The Guardian, December 28, 2000, sec. UK news, https://www.theguardian.com/uk/2000/dec/28/india.kashmir.

46. Telegraph Reporting Team, "Britain First Leader and Deputy Jailed for ReligiouslyAggravated Harassment over 'hostility' towards Muslims," The Telegraph, March 7, 2018, https://www.telegraph.co.uk/news/2018/03/07/britain-first-leader-deputy-guilty-religiouslyaggravated-harassment/.

47. C. Sylvester, "Empathetic Cooperation: A Feminist Method For IR," Millennium - Journal of International Studies 23, no. 2 (June 1994): 315-334, https://doi.org/10.1177/03058298940230021301; Adam Dolnik, ed., Conducting Terrorism Field Research: A Guide (Abingdon, Oxon; New York, NY: Routledge, 2013); Adam Dolnik, "Conducting Field Research on Terrorism: A Brief Primer," Perspectives on Terrorism 5, no. 2 (May 6, 2011), http://www.terrorismanalysts.com/ pt/index.php/pot/article/view/dolnik-conducting-field-research.

48. Marc Sageman, Misunderstanding Terrorism (Philadelphia, Pennsylvania: University of Pennsylvania Press, 2016), 20.

49. Kathleen M. Blee, "Ethnographies of the Far Right," Journal of Contemporary Ethnography 36, no. 2 (January 4, 2007): 119-28, https://doi.org/10.1177/0891241606298815; Pilkington, Loud and Proud; Esseveld, J. and Eyerman, R. (1992) cited in Pilkington.

50. Kimmel, Healing from Hate; Sageman, Leaderless Jihad.

51. Robinson Speech, Pegida $2^{\text {nd }}$ Anniversary, Dresden, October 2016. Pegida stands for Patriotische Europäer Gegen die Islamisierung des Abendlandes, which translates to, Patriotic Europeans Against the Islamization of the West.

52. Ibid.

53. Fransen, Speech, Britain First demonstration, 22 July 2017

54. Interview, Tommy Robinson, 10 March 2017

55. Interview, Jayda Fransen, 5 April 2017

56. James Fergusson, Al-Britannia, My Country: A Journey Through Muslim Britain (Bantam Press, 2017), https://www.amazon.co.uk/dp/B01MTCJHS1/ref=dp-kindle-redirect?_encoding= UTF8\&btkr=1. See also https://www.jaydafransen.online/

57. Coulter is an American conservative commentator who has been outspoken on Islam and immigration as threats. 
58. Interview, Anne Marie Waters, 14 October 2016

59. Ibid.

60. For instance, in the 2000s leader of al-Qaeda in Iraq Abu Musab al-Zarqawi used women as suicide bombers to shame men into action.

61. For more on the issue of female masculinities see Halberstam, Female Masculinity; Beasley, Gender and Sexuality; Gayle S. Rubin, "Thinking Sex: Notes for a Radical Theory of the Politics of Sexuality," in Deviations: A Gayle Rubin Reader (Duke University Press, 2011), https://doi.org/10.1215/9780822394068.

62. See David Cameron, "PM's Speech at Munich Security Conference" (Munich Security Conference, February 2011), http://webarchive.nationalarchives.gov.uk/20130109092234/ http://number10.gov.uk/news/pms-speech-at-munich-security-conference/for the equation of gender equality with a counter-radicalisation agenda.

63. Niels Spierings and Andrej Zaslove, "Conclusion: Dividing the Populist Radical Right between 'Liberal Nativism' and Traditional Conceptions of Gender," Patterns of Prejudice 49, no. 1-2 (March 15, 2015): 163-73, https://doi.org/10.1080/0031322X.2015.1024466; Nira Yuval-Davis, "Women and the Biological Reproduction of 'The Nation," Women's Studies International Forum 19, no. 1/2 (1996): 17-24; Daniella Sarnoff, "Domesticating Fascism: Family and Gender in French Fascist Leagues," in Women and the Right: Comparisons and Interplay Across Borders, ed. Kathleen M. Blee and Sandra McGee Deutsch (Penn State University Press, 2012), 163-76, http://muse.jhu.edu/chapter/491445.

64. Pierre Bourdieu, Outline of a Theory of Practice, trans. Richard Nice, 1 edition (Cambridge University Press, 1977), 90-93; Fowler, "Reading Pierre Bourdieu's Masculine Domination: Notes Towards An Intersectional Analysis of Gender Culture and Class," 471.

65. See Pilkington, "EDL Angels Stand beside Their Men ... Not behind Them."

66. Pilkington, Loud and Proud; Busher, The Making of Anti-Muslim Protest.

67. See for instance the representation of the white working class in this article in the (conservative) Telegraph newspaper David Millward, "White Working Class Is Becoming a Dying Breed in the East End Borough of Newham According to BBC Documentary," The Telegraph, May 15, 2016, https://www.telegraph.co.uk/news/2016/05/15/white-working-classis-becoming-a-dying-breed-in-the-east-end-bo/.

68. Steve Hall, "Daubing the Drudges of Fury Men, Violence and the Piety of the "Hegemonic Masculinity' Thesis," Theoretical Criminology 6, no. 1 (January 2, 2002): 35-61, https://doi. org/10.1177/136248060200600102; Treadwell and Garland, "Masculinity, Marginalization and Violence: A Case Study of the English Defence League."

69. Thomas Hegghammer, "Introduction," in Jihadi Culture: The Art and Social Practices of Militant Islamists, ed. Thomas Hegghammer (Cambridge, United Kingdom: Cambridge University Press, 2017), 2.

70. Michael Kenney, The Islamic State in Britain: Radicalization and Resilience in an Activist Network (Cambridge: Cambridge University Press, 2018), 99, https://doi.org/10.1017/ 9781108557108.

71. Interview, Anjem Choudary, 18 July 2016

72. Interview, Anjem Choudary, 18 July 2016

73. Ibid.

74. Quintan Wiktorowicz, Radical Islam Rising: Muslim Extremism in the West (Lanham, Md: Rowman \& Littlefield Publishers, Inc., 2005); Yasmin Mulbocus, Telephone Interview with Yasmin Mulbocus, former Al Muhajiroun Activist, August 2013.

75. Akash is one of the few who told me his wife opposes his views.

76. Interview, Mo, 8 October 2016

77. Mattheis and Winter, "The Greatness of Her Position':"

78. Interview, Saleha, 16 August 2016

79. Interview, Aisha, 10 April 2017

80. Robert Lambert, "Salafi and Islamist Londoners: Stigmatised Minority Faith Communities Countering al-Qaida," Crime, Law and Social Change 50, no. 1-2 (May 2008): 73-89, https://doi.org/10.1007/s10611-008-9122-8; Annabel Inge, The Making of a Salafi Muslim 
Woman (Oxford: Oxford University Press, 2016), https://global.oup.com/academic/product/ the-making-of-a-salafi-muslim-woman-9780190611675? cc=gb\&lang=en\&.

81. Nelly Lahoud, "EMPOWERMENT OR SUBJUGATION: An Analysis of ISIL's Gendered Messaging" (UN Women, 2018); Elizabeth Pearson and Emily Winterbotham, "Women, Gender and Daesh Radicalisation," The RUSI Journal 0, no. 0 (July 28, 2017): 1-13, https:// doi.org/10.1080/03071847.2017.1353251.

82. Interview, Rifat, 21 May 2017

83. Ibid.

84. Hegghammer, "8. Non-Military Practices in Jihadi Groups."

85. Spierings and Zaslove, "Gendering the Vote for Populist Radical-Right Parties," 143.

86. Donald Holbrook, "Far Right and Islamist Extremist Discourses: Shifting Patterns of Enmity," in Extreme Right Wing Political Violence and Terrorism, ed. Max Taylor (London; New York: Bloomsbury Academic, 2013), 228.

87. Kathleen M. Blee, "Women and Organized Racial Terrorism in the United States," in Female Terrorism and Militancy: Agency, Utility, and Organization, ed. Cindy D. Ness, 1 edition (London; New York: Routledge, 2008), 201-16; Blee, "Becoming A Racist: Women in Contemporary Ku Klux Klan and Neo-Nazi Groups"; Blee and Creasap, "Conservative and Right-Wing Movements."

88. Matthew Feldman, "From Radical-Right Islamophobia to 'Cumulative Extremism"” (Faith Matters, 2012), http://www.safecampuscommunities.ac.uk/uploads/files/2016/08/faith_ matters_islamophobia_report_requires_upload.pdf; Paul Jackson and Matthew Feldman, “The EDL: Britain's 'New Far Right' Social Movement" (Northampton: University of Northampton, 2011).

89. Lange and Mügge, "Gender and Right-Wing Populism in the Low Countries," 62.

90. Yuval-Davis, "Women and the Biological Reproduction of 'The Nation," 22-23.

91. Lahoud, "The Neglected Sex: The Jihadis' Exclusion of Women From Jihad"; Lahoud, "EMPOWERMENT OR SUBJUGATION: An Analysis of ISIL's Gendered Messaging"; Margaret Gonzalez-Perez, Women and Terrorism: Female Activity in Domestic and International Terror Groups, 1 edition (London; New York: Routledge, 2008); Jytte Klausen, "Tweeting the Jihad: Social Media Networks of Western Foreign Fighters in Syria and Iraq," Studies in Conflict \& Terrorism 38, no. 1 (January 2, 2015): 1-22, https://doi.org/10.1080/ 1057610X.2014.974948.

92. Kimmel, Healing from Hate; Sageman, Leaderless Jihad.

93. Hegghammer, "Introduction."

94. Busher, The Making of Anti-Muslim Protest, paras. 68-74.

95. Jonathan Githens-Mazer, "The Rhetoric and Reality: Radicalisation and Political Discourse," International Political Science Review 33, no. 5 (October 24, 2012): 556-67, https://doi.org/ $10.1177 / 0192512112454416$.

\section{Disclosure statement}

No potential conflict of interest was reported by the author(s).

\section{Funding}

This work was supported by King's College London and the Economic and Social Research Council [grant number 1433845].

\section{ORCID}

Elizabeth Pearson (D) http://orcid.org/0000-0003-0918-6107 